\title{
20. Analysis of Household Expenditure and Household Waste Generation in Taiwan 台湾における家計消費と家庭ごみ発生量の分析
}

\author{
Yu-Chi Weng*, Takeshi Fujiwara*, Yuzuru Matsuoka*

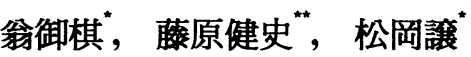

\begin{abstract}
Social, economic and environment is a composite dynamic system. "Mass production, and mass consumption, and mass discarded waste" has been a popular phenomenon in modern society, especially in developing countries. Literatures have indicated consumption is a driving factor of environmental loads but only few give quantitative results. In this study, individual's waste generation by waste component category is simulated via simultaneous equation system regarding for the consumption structure by a case study of Taiwan. Firstly, precise estimation models are developed, and analysis results not only identify the household waste generation loads of consumer's behavior explicitly, but also provide an analytic framework to evaluate performance of relevant policies.
\end{abstract}

Keywords: Taiwan, Household Waste, Household Expenditure, Simultaneous Equation System.

\section{Introduction}

As the proceeding of industrialization and civilization, many countries made great economic growth in the last few decades. "Can economic growth be harmony with the environment?" has been a classical debate for decades. More and more public opinion and research regarded production and consumption as an important driving force of global environmental problems (Vitousek et al., 1997; Jackson and Marks, 1999; OECD, 2002; O'Hara and Stagl, 2002; Kanamori and Matsuoka, 2006). They also pointed out that unsustainable consumption is arisen from contemporary lifestyle. Such consumption structure and mechanism has great potential enlarging the environmental loads - especially on household waste generation. Estimation of the generation of solid waste is the most fundamental and important issue of solid waste management; it plays an important role in the design of waste treatment system capacity. Vast environmental risk and externality exists in the treatment and disposal of household waste, but less and less land space is available for final disposal site. Estimation and forecasting the generation of household waste has become the most critical issue in municipal solid waste management system.

As previous discussion, house waste generation results from large consumption activities. Since more and more researches are focusing on the relationship between household waste generation and consumer's behavior but only few quantitative studies of this topic are obtained. Moreover, although total waste generation has been estimated by using many kinds of statistical models, but no research estimates the amount of waste in each component category - this information determines the capacity of treatment, recycling, and disposal system. Therefore, this paper presents a quantitative household waste estimation model system from the point of view of consumption expenditure and conduct a case study in Taiwan, a developing country. If such quantitative model system is developed, a more environmental-friendly consumption behavior could be proposed. Furthermore, such information is beneficial for advanced municipal solid waste management and the policy design of circular society.

\section{Characteristics of the conversion process of consumed goods into waste}

As mentioned previously, literatures point out consumption is a critical driving factor of the household waste

\footnotetext{
* 京都大学大学院 工学研究科 都市環境工学専攻 Department of Urban and Environmental Engineering, Graduate School of Engineering, Kyoto University

** 岡山大学大学院 環境学研究科 資源循環学専攻 Division of Sustainability of Resources, Graduate School of Environmental Science, Okayama University
} 
generation. For the purpose of making precise waste estimation, it is necessary to explore the relationship between the individual's consumption and his/her waste generation. The main concept is that waste is the discarded goods which are broken or useless after being utilized. There are several characteristics of the fate of the consumed goods in the conversion process:

Firstly, one kind of goods may be disaggregated and distributed into several categories of waste. For example, it is possible for a can food to generate two kind of waste (food waste and metal waste) in the consumption and utilization process. Thus correspondence among categories of consumed goods and categories of waste should be considered simultaneously. Secondly, waste has its own retention time in household. The time period of goods in use depends on characteristics of the goods (durable or non-durable). Thus waste generation process is a highly dynamic process. Thirdly, in the utilization process, a part of the weight of goods may be lost or added and then converted into waste. For example, moisture of the same kind of waste usually changes spatially and temporally; also, eaten food almost decrease to a great extent in its residual. Furthermore, data of the amount of consumed goods is hardly available for most countries; thus regular per capita household expenditure is a suitable substitute index. These factors signify the uncertainty in the estimation of waste generation. In order to deal with such uncertainty, statistical modeling is effective; thus statistical modeling is applied in this study according to previous principles and taking waste elimination measures by government into consideration.

\section{Model Strategies}

Up to now, many statistical models (e.g., time series analysis, grey fuzzy dynamic modeling, system dynamics and simultaneous equation system) have been developed in solid waste estimation and forecasting for different purpose (Chang and Lin, 1997; Chen and Chang, 2000; Navarro-Esbri' et al., 2002; Dyson and Chang, 2005; Heijungs and Suh, 2006). Among these approaches, simultaneous equation system is chosen in this study. Simultaneous equation system, in which all the parameters of equations are estimated simultaneously, may account for the interaction among various endogenous variables. Besides, results of simultaneous equation system can be interpreted straightforwardly (Pindyck and Rubinfeld, 1998). Additionally, this approach is recommended for mass balance simulation (Heijungs and Suh, 2006). Thus simultaneous equation system is the most appropriate approach in establishing the waste estimation model by waste component category considering consumption behavior (which is revealed through the expenditure structure). Let $\Theta$ denotes waste component categories, i.e. $\Theta \in\{$ plastics waste, paper wast $e$, food waste,..$\}$, the simultaneous equation system is constructed as follows:

(i) Waste composition equation:

$$
\begin{aligned}
& W G_{s}=\alpha+x^{\mathrm{T}} \delta \\
& W G_{i}=\alpha_{i}+x^{\mathrm{T}} \delta_{i} \quad \forall i \in \Theta
\end{aligned}
$$

(ii) Balance equation:

$$
W G_{s}=\sum_{i \in \Theta} W G_{i}
$$

where $W G_{s}$ is annual per capita waste generation; $W G_{i}$ denotes the set of the quantities in household waste component categories, $\Theta ; x$ is a column vector of individual's expenditure category (including major expenditure categories and minor ones); $\alpha$ and $\delta$ are column vectors of parameters. The coefficient of explanatory variable designates the marginal impact of the variable in the equation, thus makes the relation among variables explicit.

In simultaneous equation system, quantity of each waste component category and the total per capital waste generation serve as endogenous variables; the amount of each individual's expenditure by category are exogenous variables. Model fitting is performed by two steps. At first, single equations for each category of waste composition are developed separately; the most reasonable structure of the equation system is confirmed in this step. Secondly, overall equation system is simulated by Newton's method. Since parameters are specified simultaneously, the interaction among models could be compactly linked, and the best result is obtained (Bronwyn and Clint, 2005). 
Mean absolute percent error $(M A P E)$ is used to evaluate the modeling performance, and it is calculated as follows:

$$
M A P E=\frac{1}{N} \sum_{s=1}^{N} \frac{\left|\hat{Y}_{s}-Y_{s}\right|}{Y_{s}}
$$

where $Y_{s}$ and $\hat{Y}_{s}$ are the original series and the estimates, respectively; $N$ is length of the series.

\section{Case Study}

\subsection{Background of study area}

Taiwan is a small island with limited natural resource but with almost the densest population around the world: over 22,000 thousand people live within 36,000 square kilometers. Taiwan government made great economic achievement by adjusting the economic structure from agriculture to industry and service sectors in the last few decades. After the rising of democratization, industrialization, and urbanization, lifestyle and consumer's behavior changed dramatically; like other developing countries, environmental problems in Taiwan are increasing rapidly.

As mentioned previously, household waste estimation modeling is conducted on the basis of consumption behavior. Since data of the amount of consumed goods is unavailable in Taiwan, we use per capita household expenditure from official databases (Directorate-General of Budget, Account and Statistics, 2006) as a substitute index. Table 1 lists the categories classified in of household expenditure in Taiwan; Fig. 1 shows the structure change of individual's expenditure in major category; Table 2 shows these changes from 1992 to 2004 . Obviously almost the expenditure categories increased over the period, especially for the "medicine \& medical care", "transportation \& communication", and "amusement \& education" items. These changes are deeply affected by economic factors and lifestyle changes, and then the consumption behavior results in the waste generation.

Facing the lifestyle changes in Taiwan, Environmental Protection Agency (EPA) and its previous administrations has executed several countermeasures to control the rapidly growing solid waste generation both for household and industrial waste from 1974 (EPA, 2007). Furthermore, several administrative projects played important roles on controlling the household waste generation according to supportive regulations (Bor et al., 2004).

Fig. 2 illustrates the official records of the structure of household waste generation in Taiwan; the dataset is from 1992 to 2004 (EPA, 2006). In this study, household waste is classified into seven categories by physical property for the purpose of treatment and final disposal plan: paper, plastics, food, moisture, metal \& glass, miscellaneous item of the combustibles, and miscellaneous item of the incombustible. Because the composition survey is conducted by dry basis of waste analysis before 2004, moisture is separated as a single item. By such classification, essential information will be obtained for the design of recycling, treatment, and disposal plans.

In Fig. 2 we find per capita household waste generation is a ragged series which is due to policy interventions. At the beginning, people in Taiwan did

\begin{tabular}{|c|c|c|}
\hline Major Category & Minor Category & \\
\hline \multirow[t]{7}{*}{$\begin{array}{l}\text { Food } \\
\text { (Fd) }\end{array}$} & $\begin{array}{l}\text { Cereals \& cereal products } \\
\text { Meat and meat products }\end{array}$ & $\left(\mathrm{HPFd}_{1}\right)$ \\
\hline & Milk and milk products & $\left(\mathrm{HPFd}_{2}\right)$ \\
\hline & Vegetables & $\left(\mathrm{HPFd}_{3}\right)$ \\
\hline & Miscellaneous food commodity & $\left(\mathrm{HPFd}_{4}\right)$ \\
\hline & Food out from home & $\left(\mathrm{HPFd}_{5}\right)$ \\
\hline & Beverages & $\left(\mathrm{HPFd}_{6}\right)$ \\
\hline & Tobacco and betel nut & $\left(\mathrm{HPFd}_{7}\right)$ \\
\hline \multirow{2}{*}{$\begin{array}{l}\text { Clothing } \\
\text { (Cloth) }\end{array}$} & Garments & (HPCloth $\left.{ }_{1}\right)$ \\
\hline & Footwear & $\left(\right.$ HPCloth $\left._{2}\right)$ \\
\hline \multirow{5}{*}{$\begin{array}{l}\text { Housing } \\
\text { (House) }\end{array}$} & Residential rent & (HPHouse ${ }_{1}$ ) \\
\hline & Maintenance and repairs & (HPHouse $\left.{ }_{2}\right)$ \\
\hline & Water supply & (HPHouse $\left.{ }_{3}\right)$ \\
\hline & Facility insurance fee & (HPHouse ${ }_{4}$ ) \\
\hline & Electricity and gas supply & (HPHouse $)$ \\
\hline \multirow{5}{*}{$\begin{array}{l}\text { Household Appliances } \\
\text { (HA) }\end{array}$} & Furniture & $\left(\mathrm{HPHA}_{1}\right)$ \\
\hline & Fabric products & $\left(\mathrm{HPHA}_{2}\right)$ \\
\hline & Household durable equipment & $\left(\mathrm{HPHA}_{3}\right)$ \\
\hline & \begin{tabular}{|l|} 
Tableware and other utensils \\
\end{tabular} & $\left(\mathrm{HPHA}_{4}\right)$ \\
\hline & Household keeping services & (HPHA $A_{5}$ \\
\hline \multirow{4}{*}{$\begin{array}{l}\text { Medicines and Medical Care } \\
\text { (Med) }\end{array}$} & Medical supplies and appliance & $\left(\mathrm{HPMed}_{1}\right)$ \\
\hline & Medical care services & $\left(\mathrm{HPMed}_{2}\right)$ \\
\hline & Medicines and health food & $\left(\mathrm{HPMed}_{3}\right)$ \\
\hline & Health insurance & $\left(\mathrm{HPMed}_{4}\right)$ \\
\hline \multirow{4}{*}{$\begin{array}{l}\text { Transportation and } \\
\text { Communication } \\
\text { (Trans) }\end{array}$} & \begin{tabular}{|c|} 
Transportation and communication \\
equipment
\end{tabular} & (HPTrans $\left.{ }_{1}\right)$ \\
\hline & \begin{tabular}{|c|} 
Parts and repair charge of \\
transportation equipment
\end{tabular} & (HPTrans $\left.)_{2}\right)$ \\
\hline & Transportation fees and insurance & (HPTrans 3 ) \\
\hline & Communication services & $\left(\right.$ HPTrans $\left._{4}\right)$ \\
\hline \multirow{5}{*}{$\begin{array}{l}\text { Amusement and Education } \\
\text { (AE) }\end{array}$} & \begin{tabular}{|l|} 
Traveling expense \\
\end{tabular} & $\left(\mathrm{HPAE}_{1}\right)$ \\
\hline & Entertainment expense & $\left(\mathrm{HPAE}_{2}\right)$ \\
\hline & Book, newspaper and periodical & $\left(\mathrm{HPAE}_{3}\right)$ \\
\hline & Entertainment equipment & $\left(\mathrm{HPAE}_{4}\right)$ \\
\hline & Educational expense & $\left(\mathrm{HPAE}_{5}\right)$ \\
\hline \multirow{7}{*}{$\begin{array}{l}\text { Miscellaneous } \\
\text { (Mis) }\end{array}$} & Miscellaneous commodity & $\left(\mathrm{HPMis}_{1}\right)$ \\
\hline & Financial service & $\left(\mathrm{HPMis}_{2}\right)$ \\
\hline & Cosmetic items & $\left(\mathrm{HPMis}_{3}\right)$ \\
\hline & Personal care services & $\left(\mathrm{HPMis}_{4}\right)$ \\
\hline & $\begin{array}{r}\text { Wedded and funeral expense } \\
\text { (exclusive of food charge) }\end{array}$ & (HPMis $\left.s_{\varsigma}\right)$ \\
\hline & Miscellaneous expense & (HPMis 6 \\
\hline & Other non-saving insurance expense & $\left(\mathrm{HPMis}_{7}\right)$ \\
\hline
\end{tabular}


not notice the importance of waste problems. Almost all the waste directly was dumped into landfill sites without proper separation. In the 1980's, some landfill sites were fulfilled; household waste in some cities even had no place to be dumped temporally. At that time, EPA turned the treatment approach to incineration. The first incinerator was operated in 1992, and most of planned incinerators were operated during 1998 to 2001 and handled more than 90\% household waste after 2001. In order to keep good performance of incinerators, EPA made extensive social education for the citizens to reduce the moisture of waste and to conduct household waste separation. An important household waste elimination project-"Resource Recycling Four-in-One Project”, starting from 1997-not only improved the waste recycling system but arouse the public concern for household waste issues. In addition, non-governmental groups devoted themselves to recycling affairs. For the controlling of dioxin emitted by incinerators, EPA started to limit the use of plastics bags and some plastics products in 2002 ("Limitation on the Utilization of Plastics Usage"). Therefore five dummy variables are set in the model system: $D u m_{I}$ and $D u m_{3}$ denote the projects imposed in 1997 and 2002, respectively; Dum 2 represents transaction of public behavior about household waste collection affected by the public education and citizens' environmental consciousness. On the contrast, Dum 12 and Dum $_{22}$ denote the original situation before these actions imposed. Respective definition of the variables in the model development is described in Table 3.

\subsection{Results and discussion}

Simultaneous equation system is used in the model development. At first, quantity of each waste category is estimated separately by ordinary least square (OLS) method; then all the equations are simulated simultaneously. Some expenditure variables are merged appropriately to prevent the model from colinearity problem. Estimators of separate equation at the first stage are listed in the beginning of the next page ( $t$ statistics in parentheses).

As mentioned in section 2 , the uncertainty of goods converted into waste lower the performance for some equations (low adjusted $R^{2}$ values). More detail
Table 2 Changes in major category of per capita household expenditure from 1992 to 2004.

\begin{tabular}{lc}
\hline \multicolumn{1}{c}{ Expenditure Category } & Increase Rate (\%) \\
\hline Annual per capita expenditure & 68.09 \\
Food & 34.67 \\
Clothing & -3.75 \\
Housing & 47.91 \\
Household appliances & 50.27 \\
Medicines and medical care & 330.00 \\
Transportation and communication & 136.54 \\
Amusement and education & 68.57 \\
Miscellaneous & 100.72 \\
\hline
\end{tabular}

Table 3 Description of variables used in the model development.

\begin{tabular}{|c|c|c|}
\hline Variable & Description & Unit \\
\hline$W G_{s}, W G_{s}^{(\mathrm{t}-1)}$ & $\begin{array}{l}\text { Annual per capita aggregate household waste } \\
\text { generation and its lag term. }\end{array}$ & $\mathrm{kg}$ \\
\hline$W G_{i}, W G_{i}^{(\mathrm{t}-1)}$ & $\begin{array}{l}\text { Annual per capita general waste generation by } \\
\text { seven categories and its lag term } \\
i=\text { paper, plastics, food, moisture, } \\
\text { miscellaneous item of the } \\
\text { combustible(abbreviated as "mis-c"), metal } \\
\text { and glass (abbreviated as "metgla"), } \\
\text { miscellaneous item of the incombustible } \\
\text { (abbreviated as "mis-inc"); }\end{array}$ & $\mathrm{kg}$ \\
\hline Cons & Annual per capita household expenditure & $\begin{array}{l}10^{4} \text { Taiwan } \\
\text { dollar(\$NT) per year } \\
\text { at } 2001 \text { price basis }\end{array}$ \\
\hline$H P F d_{j}$ & $\begin{array}{l}\text { Annual per capita household expenditure on } \\
\text { Food of minor category } \mathrm{j} \text { (see Table 1); }\end{array}$ & $\begin{array}{l}10^{4} \$ N T \text { per year at } \\
2001 \text { prices basis }\end{array}$ \\
\hline HPHouse $_{j}$ & $\begin{array}{l}\text { Annual per capita household expenditure on } \\
\text { Housing of minor category } j \text { (see Table 1); }\end{array}$ & $\begin{array}{l}10^{4} \$ N T \text { per year at } \\
2001 \text { price basis }\end{array}$ \\
\hline$H P A E_{j}$ & $\begin{array}{l}\text { Annual per capita household expenditure on } \\
\text { Amusement \& Education of minor category } j \\
\text { (see Table 1); }\end{array}$ & $\begin{array}{l}10^{4} \$ N T \text { per year at } \\
2001 \text { price basis }\end{array}$ \\
\hline Dum $_{l}$ & $\begin{array}{l}\text { Dummy variable for the "Resource Recycling } \\
\text { Four-in-One Project" action--before 1998, } \\
\text { the value is zero and } 1 \text { otherwise. Here, one } \\
\text { year lag for the project's efficiency is } \\
\text { considered. }\end{array}$ & none \\
\hline Dum $_{12}$ & $\begin{array}{l}\text { Dummy variable, the before } 1998 \text {, the value is } \\
1 \text { and zero otherwise. }\end{array}$ & none \\
\hline $\mathrm{Dum}_{2}$ & $\begin{array}{l}\text { Dummy variable for the main treatment } \\
\text { approach changed into incineration--before } \\
2001 \text { the value is zero and } 1 \text { otherwise. }\end{array}$ & none \\
\hline Dum $_{22}$ & $\begin{array}{l}\text { Dummy variable, the before } 2001 \text {, the value is } \\
1 \text { and zero otherwise. }\end{array}$ & none \\
\hline $\mathrm{Dum}_{3}$ & $\begin{array}{l}\text { Dummy variable for the "Limitation on the } \\
\text { Utilization of Plastics Usage" action-before } \\
2002 \text {, the value is zero and } 1 \text { otherwise. }\end{array}$ & none \\
\hline
\end{tabular}

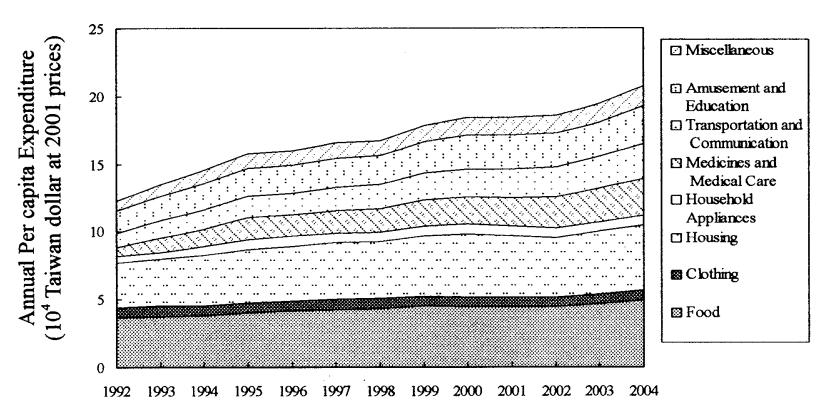

Fig. 1 Structure of per capita household expenditure in Taiwan from 1992 to 2004.

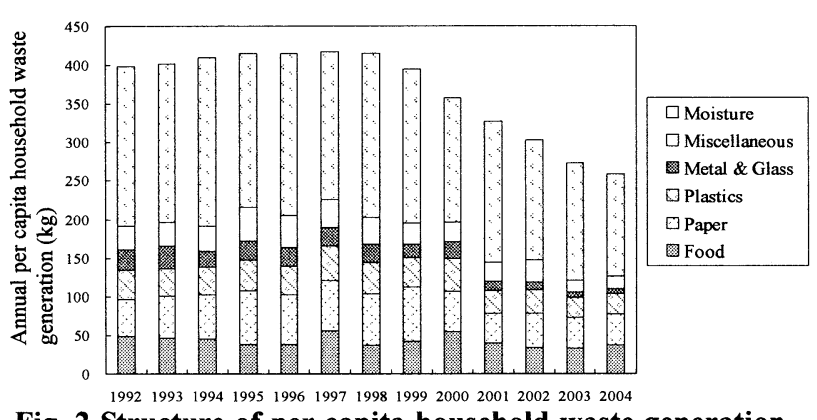

Fig. 2 Structure of per capita household waste generation in Taiwan from 1992 to 2004. 
(i) Waste composition equation:

$$
\begin{aligned}
& W G_{s}=\underset{(8.94)}{338.432}+\underset{(1.89)}{4.816} \times \text { Cons } \times \text { Dum }_{12}+\underset{(15.19)}{1.027} \times W_{s}(t-1)-\underset{15.19)}{370.839} \times \text { Dum }_{1} \\
& \text { Adjusted } R^{2}=0.974, F=150.316 \\
& W G_{\text {paper }}=-41.134+\underset{(-1.09)}{736.51} \times H_{(2.69)} \text { PAE }_{3}-\underset{(-2.85)}{15.289} \times \text { Dum }_{1} \\
& \text { Adjusted } R^{2}=0.431, F=5.51 \text {; } \\
& W G_{\text {plastics }}=38.559+0.263 \times(F d+A E)-12.523 \times \text { Dum }_{3} \\
& \text { (2.62) (0.11) (-3.32) } \\
& \text { Adjusted } R^{2}=0.582, F=9.36 \text {; } \\
& W G_{\text {food }}=\underset{(1.47)}{43.302}+\underset{(0.69)}{0.497} \times F d \times \text { Dum }_{22}-\underset{(-2.45)}{7.242} \times \text { Dum }_{2} \\
& \text { Adjusted } R^{2}=0.245, F=2.947 \text {; } \\
& W G_{\text {miosture }}=194.064+0.0054 \times W G_{\text {miosture }}(t-1)-46.882 \times \text { Dum }_{2} \\
& \stackrel{(3.13)}{R^{2}=0.757, F=18.169} \\
& \left.W G_{\text {metgla }}=\underset{(10.54)}{10.645 \times\left(H P F d_{1}+H P F d_{4}\right.}+H_{P F d_{6}}+\text { HPHouse }_{3}+\text { HPHouse }_{4}\right)-\underset{(-3.71)}{12.409 \times \text { Dum }_{1}} \\
& \text { Adjusted } R^{2}=0.431, F=9.987 \\
& W G_{m i s-c}=12.315+0.601 \times W G_{m i s-c}(t-1)-5.431 \times \text { Dum }_{1} \\
& \text { (1.75) (2.43) } \quad(-2.00) \\
& \text { Adjustred } R^{2}=0.583, F=8.685 \\
& W G_{m i s-i n c}=3.917+0.323 \times W G_{m i s-i n c}(t-1)-2.369 \times D^{2} m_{1} \\
& \text { Adjustred } R^{2}=0.546, F=7.626
\end{aligned}
$$

(ii) Balance equation:

$W G_{S}=W G_{\text {paper }}+W G_{\text {plastics }}+W G_{\text {food }}+W G_{\text {moisture }}+W G_{\text {metgla }}+W G_{\text {mis }-c}+W G_{\text {mis -inc }}$

survey should be conducted so that the characteristics of conversion process from consumed goods into waste can be caught, especially for food waste.

OLS results show that consumption is an important factor for household waste generation but insignificant after the implement of administrative projects $\left(D_{u}, D_{l} \operatorname{Dum}_{2} \text {, and Dum }\right)_{3}$. The core equation, per capital household waste generation, is constructed by two dummy variables $\left(D u m_{l}\right.$, and $\left.D u m_{12}\right)$ - this means it is developed by two time period. Before 1998, per capital household expenditure is the driving factor; but after the projects worked, consumption was not a decisive factor. Instead, project's effect becomes dominate to affecting the generation of household waste after 1998.

The relationship among consumption expenditure and waste provides the clues to eliminate waste generation by suppressing consumption on specific items in each equation. The most obvious case is the paper waste. Considering that the coefficient of explanatory variable denotes the marginal effect of the variable, per $10^{4}$ New Taiwan dollar (\$NT) on $A E_{3}$ ("Book, newspaper and periodical") averagely results in $736.51 \mathrm{~kg}$ paper waste annually (at 2001 prices). Moreover, analysis results show that individual's expenditure on "food", "housing", and "amusement \& education" are the driving factors for the generation of paper waste, metal \& glass waste, and food waste. Since the relationship between waste generation and household expenditure are modeled, present consumption structure can be examined and be adjusted into a more sustainable one; eventually sustainable household consumption will lead to more sustainable lifestyle as well.

Furthermore, analysis results suggest that projects' effects make crucial impact on the waste generation for all waste component categories, especially for potential resources (such as paper waste, plastics waste, food waste, and metal $\&$ glass waste). The marginal effect of "Resource Recycling Four-in-One Project" $\left(D_{u m}\right)$ is very significant to eliminate waste especially on per capital household generation by $370.84 \mathrm{~kg}$ and metal \& glass waste by $12.41 \mathrm{~kg}$, respectively. Besides, moisture of waste is deeply affected by the transaction of treatment technology. The marginal effect estimated for "Limitation on the Utilization of Plastics Usage" $\left(D u m_{3}\right)$ is $46.88 \mathrm{~kg}$ annually. Although incineration increases the risk of the human exposure to dioxin, it makes the citizens more aware of the seriousness of household waste problems. Consequently, these projects arouse the public concern about the waste problem, and the effects will still last vastly.

After a reliable equation structure is constructed, the equation system is modeled by Newton's method simultaneously. Table 4 illustrates the results, and the modeling result of per capita waste generation is demonstrated in Fig. 3. Simultaneous equation system makes compact interaction of waste categories and shows superior performance in model fitting than single-equation models with a reasonable model structure. 
Table 4 Modeling results of simultaneous equation system.

\begin{tabular}{lc}
\hline Waste Category & MAPE $(\%)$ \\
\hline Total Waste Generation & 1.58 \\
Paper & 11.90 \\
Plastics & 8.20 \\
Food & 10.72 \\
Moisture & 4.84 \\
Metal and Glass & 11.27 \\
Miscellaneous of the & 34.20 \\
combustible & \\
Miscellaneous of the & 38.71 \\
incombustible & \\
\hline
\end{tabular}

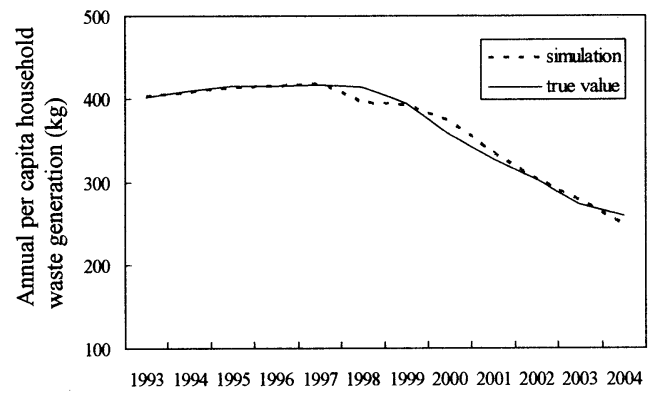

Fig. 3 Modeling of per capita household waste generation by simultaneous equation system.

\section{Conclusion}

Consumption behavior has been proved to be an important driving factor of environmental loads, especially for household waste generation. This study conducts a case study developing an integrated equation system in light of consumption expenditure, environmental policy effects, and household waste generation in Taiwan.

Accurate estimation of per capital household waste generation is obtained; estimation model of waste by component is very helpful for designing waste management system. Besides, analysis results show that individual's consumption plays an important role for household waste generation but not significant after the implement of administrative projects. Furthermore, administrative projects are quantitatively evaluated as well. But insufficient data limits model performance to catch characteristics of the conversion process from consumed goods into waste. More detail data is necessary.

To conclude, results in the case study show that the model system not only serves as useful approach to make precise of the estimation of household waste by component category but also analyze the sustainability of individual's consumption. Furthermore, this model provides an analytic framework for evaluating policy performance. In order to construct a sustainable society, environmental consciousness as well as green regulations should be highlighted in adjusting the structure of individual's consumption via this developed model system. If the unnecessary consumption is eliminated and more efficiently the goods are used, a much small amount of waste generation is expected.

\section{Reference}

1) Bor, Y. J., Chien, Y. L., Hsu, E., 2004. The market-incentive recycling system for waste packaging containers in Taiwan. Environmental Science \& Policy 7, 509-523.

2) Bronwyn, H. H., Clint C., 2005. TSP 5.0 Reference Manual. Available from < http://elsa.berkeley.edu/wp/tsp_user/07lsqfiml.pdf >, TSP International, California, USA.

3) Chang, N. B., Lin, Y. T., 1997. An analysis of recycling impacts on solid waste generation by time series intervention modeling. Resource Conservation and Recycling 19, 165-186.

4) Chen, H. W., Chang, N. B., 2000. Prediction of solid waste generation via fuzzy dynamic modeling. Resource Conservation and Recycling 29, 1-18.

5) Directorate-General of Budget, Account and Statistics, Republic of China, 2006 . Available from: $<$ http://www.dgbas.gov.tw/ct.asp?xItem $=13213 \&$ CtNode $=3504>$.

6) Dyson, B., Chang, N. B., 2005. Forecasting municipal solid waste generation in a fast-growing urban region with system dynamics modeling. Waste Management 25, 669-679.

7) EPA, Republic of China, 2007. Available from: $<$ http://www.epa.gov.tw/b/b0100.asp?Ct_Code $=05 X 0002208 X 0002350 \& L=2>$.

8) Heijungs, R., Suh, S., 2006. Reformulation of matrix-based LCI: from product balance to process balance. Journal of Cleaner Production 14, 47-51.

9) Jackson, T., Marks, N., 1999. Consumption, sustainable welfare and human needs - with reference to UK expenditure patterns between 1954 and 1994. Ecological Economics 28, 421-441.

10)Kanamori, Y., Matsuoka, Y., 2006. Proposal of household economy-environment accounts by household type. Proceedings of the Third World Congress of Environmental and Resource Economists, July 3-7, Kyoto, Japan.

11)Navarro-Esbri',J., Diamadopoulos, E., Ginestar, D., 2002. Time series analysis and forecasting techniques for municipal solid waste management. Resources, Conservation and Recycling 35, 201-214.

12)OECD, 2002. Towards sustainable household consumption? Trends and policies in OECD countries. OECD Publications, Paris, France.

13)O'Hara, S. U., Stagl, S., 2002. Endogenous preferences and sustainable development. Journal of Socioeconomics 31, $511-527$.

14)Pindyck, R. S., Rubinfeld, D. L., 1998. Econometric Models and Economic Forecasts 4th ed. McGraw-Hill Publishing Co., New York, USA.

15)Vitousek,P.M., Mooney, H. A., Lubchenco, J., and Melillo, J. M., 1997. Human domination of Earth's ecosystems. Science 277, 494-499. 